\title{
FAKTOR-FAKTOR YANG BERHUBUNGAN DENGAN PERILAKU ORANG TUA DALAM MELAKUKAN KEKERASAN VERBAL TERHADAP ANAK USIA PRA-SEKOLAH
}

\author{
Yuni Fitriana, Kurniasari Pratiwi, Andina Vita Sutanto \\ Prodi Kebidanan Akademi Kebidanan Yogyakarta \\ Jl. Parangtritis KM.6 Sewon Bantul \\ yufina_lucky@ymail.com
}

\begin{abstract}
Verbal abuse in children is all forms of greeting parents to children who are threatening, scaring, and insulting. This happens every day at home should be the safest place and refuge for children. Economic, social, employment, lack of knowledge to educate children and parents lack understanding of religion contributing cause parents do violence on their children. Parents commit verbal violence as a way to educate children is naughty and not obedient, so it is necessary to study in order to know the factors related to the behavior of parents in verbal violence against children pre-school age. Quantitative research methods with descriptive analytic approach. The research sample 76 people, with a proportionate random sampling technique. Instrument questionnaire. The research variables include variables such as age, education, economics, attitudes, knowledge, experience, environment, and the dependent variable is the verbal violent behavior. The analysis of univariate and bivariate data using chi square test. Results of this study there was no correlation with the behavior of a parent education did verbally abuse her son $(p=.767)$, there is no economic relationship with the parents' behavior on their verbal violence $(p=.248)$, there is a correlation between age of knowledge, attitude, experience and the environment there is a relationship with the parents' behavior on their verbal violence $(p<$ $0,001)$.
\end{abstract}

Keywords: verbal violence, parents, children pre-school age

\begin{abstract}
Abstrak
Kekerasan verbal pada anak merupakan semua bentuk ucapan orang tua kepada anak yang bersifat mengancam, menakuti, dan menghina. Hal ini terjadi setiap harinya di rumah yang seharusnya menjadi tempat teraman dan berlindung bagi anak. Ekonomi, lingkungan sosial, pekerjaan, kurangnya pengetahuan mendidik anak serta pemahaman agama orang tua kurang yang turut berperan menjadi penyebab orang tua melakukan kekerasan pada anaknya. Orang tua melakukan kekerasan verbal sebagai cara mendidik anak yang nakal dan tidak manut, sehingga perlu dilakukan penelitian dengan tujuan mengetahui faktor-faktor yang berhubungan dengan perilaku orang tua dalam melakukan kekerasan verbal terhadap anak usia pra-sekolah. Metode penelitian kuantitatif dengan pendekatan deskriptif analitik. Sampel penelitian 76 orang, dengan tekhnik proportionate random sampling. Alat instrumen kuesioner. Variabel penelitian meliputi variabel bebas yaitu umur, pendidikan, ekonomi, sikap, pengetahuan, pengalaman, lingkungan, dan variabel terikat yaitu perilaku kekerasan verbal. Analisa data secara univariat dan bivariat menggunakan uji chi square. Hasil penelitian ini tidak terdapat hubungan pendidikan dengan perilaku orang tua melakukan kekerasan verbal pada anaknya $(p=0,767)$, tidak terdapat hubungan ekonomi dengan perilaku orang tua melakukan kekerasan verbal pada anaknya $(p=0,248)$, terdapat hubungan umur pengetahuan, sikap, pengalaman dan lingkungan terdapat hubungan dengan perilaku orang tua melakukan kekerasan verbal pada anaknya $(p<0,001)$.
\end{abstract}

Kata Kunci : kekerasan verbal, orang tua, anak usia pra-sekolah

\section{PENDAHULUAN}

Tanpa disadari, orang tua pernah melakukan kekerasan terhadap anak. Salah satu bentuk kekerasan tersebut adalah kekerasan verbal atau kekerasan yang dilakukan lewat kata-kata yang menyakitkan. Kata-kata yang menyakitkan tersebut biasanya bermakna melecehkan kemampuan anak, menganggap anak sebagai sumber kesialan, mengecilkan arti 
si anak, memberikan julukan negatif kepada anak, dan memberikan kesan bahwa anak tidak diharapkan akan memiliki dampak jangka panjang terhadap perasaan anak dan dapat mempengaruhi citra diri mereka (Choirunnisa, 2008).

Berbagai bentuk ucapan yang bertujuan menyakiti anak akan berpengaruh kepadanya. Baik dalam kehidupan saat ini maupun di masa yang akan datang. Kekerasan verbal terhadap anak akan menumbuhkan sakit hati hingga membuat mereka berpikir seperti yang kerap diucapkan oleh orangtuanya. Jika orangtua bilang anak bodoh atau jelek, maka dia akan menganggap dirinya demikian. Meski dampaknya tidak terjadi secara langsung, namun melalui proses (Choirunnisa, 2008).

Ucapan-ucapan bernada menghina dan merendahkan itu akan direkam dalam pita memori anak. Semakin lama, maka akan bertambah berat dan membuat anak memiliki citra negatif. Anak yang sering mengalami kekerasan verbal di kemudian hari akan hilang rasa percaya dirinya. Bahkan hingga memicu kemarahannya, merencanakan untuk melakukan aksi balas dendam, dan berpengaruh terhadap caranya bergaul (Irwanto, 2000).

Verbal abuse atau biasa disebut emotional child abuse adalah tindakan lisan atau perilaku yang menimbulkan konsekuensi emosional yang merugikan. Verbal abuse terjadi ketika orang tua menyuruh anak untuk diam atau jangan menangis. Jika anak mulai bicara, ibu terus menerus menggunakan kekerasan verbal seperti "kamu bodoh". "kamu cerewet", "kamu kurang ajar". Anak akan mengingat itu semua kekerasan verbal jika semua kekerasan verbal itu berlangsung dalam satu periode.

Bentuk dari verbal abuse adalah sebagai berikut:
1. Tidak sayang dan dingin

Tindakan tidak sayang dan dingin ini berupa misalnya : menunjukan sedikit atau tidak sama sekali rasa sayang kepada anak (seperti pelukan), kata-kata sayang.

2. Intimidasi

Tindakan intimidasi bisa berupa : berteriak, menjerit, mengancam anak, dan mengertak anak.

3. Mengecilkan atau mempermalukan anak

Tindakan mengecilkan atau mempermalukan anak dapat berupa seperti : merendahkan anak, mencela nama, membuat perbedaan negatif antar anak, menyatakan bahwa anak tidak baik, tidak berharga, jelek atau sesuatu yang didapat dari kesalahan.

4. Kebiasaan mencela anak

Tindakan mencela anak bisa dicontohkan seperti : mengatakan bahwa semua yang terjadi adalah kesalahan anak.

5. Mengindahkan atau menolak anak

Tindakan tidak mengindahkan atau menolak anak bisa berupa : tidak memperhatikan anak, memberi respon dingin, tidak peduli dengan anak.

6. Hukuman ekstrim

Tindakan hukuman ekstrim bisa berupa: mengurung anak dalam kamar mandi, mengurung dalam kamar gelap. Mengikat anak di kursi untuk waktu lama dan meneror.

Kekerasan yang dialami oleh anak dapat berdampak pada fisik maupun psikologis. Verbal abuse biasanya tidak berdampak secara fisik kepada anak, tetapi dapat merusak anak beberapa tahun kedepan. Verbal abuse yang dilakukan orang tua menimbulkan luka lebih dalam pada kehidupan dan perasaan anak melebihi perkosaan (Soetjiningsih, 2002). Berikut dampak-dampak psikologis akibat kekerasan verbal pada anak (Ria, 2008; Widyastuti, 2006) : Anak menjadi tidak 
peka dengan perasaan orang lain, menganggu perkembangan, anak menjadi agresif, gangguan emosi, hubungan sosial terganggu, kepribadian sociopath atau antisocial personality disosder, menciptakan lingkaran setan dalam keluarga, dan bunuh diri

Beberapa faktor yang mempengaruhi orang tua melakukan verbal abuse, diantaranya (Soetjiningsih, 2002) :

1. Faktor Intern

a) Faktor pengetahuan orang tua

Kebanyakan orang tua tidak begitu mengetahui atau mengenal informasi mengenai kebutuhan perkembangan anak, misalnya anak belum memungkinkan untuk melakukan sesuatu tetapi karena sempitnya pengetahuan orang tua anak dipaksa melakukan dan ketika memang belum bisa dilakukan orang tua menjadi marah, membentak dan mencaci anak. Orang tua yang mempunyai harapan-harapan yang tidak realistik terhadap perilaku anak berperan memperbesar tindakan kekerasan pada anak. Serta kurangnya pengetahuan orang tua tentang pendidikan anak dan minimnya pengetahuan agama orang tua melatarbelakangi kekerasan pada anak.

b) Faktor pengalaman orang tua

Orang tua yang sewaktu kecilnya mendapat perlakuan salah merupakan situasi pencetus terjadinya kekerasan pada anak. Semua tindakan kepada anak akan direkam dalam alam bawah sadar mereka dan akan dibawa sampai kepada masa dewasa. Anak yang mendapat perilaku kejam dari orang tuanya akan menjadi agresif dan setelah menjadi orang tua akan berlaku kejam pada anaknya. Orang tua yang agresif akan melahirkan anak-anak yang agresif, yang pada gilirannya akan menjadi orang dewasa yang agresif pula. Gangguan mental (mental disorder) ada hubungannya dengan perlakuan buruk yang diterima manusia ketika dia masih kecil.

2. Faktor Ekstern

a) Faktor ekonomi

Sebagian besar kekerasan rumah tangga dipicu faktor kemiskinan, dan tekanan hidup atau ekonomi. Pengangguran, PHK, dan beban hidup lain kian memperparah kondisi itu. Faktor kemiskinan dan tekanan hidup yang selalu meningkat, disertai dengan kemarahan atau kekecewaan pada pasangan karena ketidakberdayaan dalam mengatasi masalah ekonomi menyebabkan orang tua mudah sekali melimpahkan emosi kepada orang sekitarnya. Anak sebagai makhluk lemah, rentan, dan dianggap sepenuhnya milik orang tua, sehingga menjadikan anak paling mudah menjadi sasaran dalam meluapkan kemarahannya. Kemiskinan sangat berhubungan dengan penyebab kekerasan pada anak karena bertambahnya jumlah krisis dalam hidupnya dan disebabkan mereka mempunyai jalan yang terbatas dalam mencari sumber ekonomi.

b) Faktor lingkungan

Faktor lingkungan juga mempengaruhi tindakan kekerasan pada anak. Lingkungan hidup dapat meningkatkan beban perawatan pada anak. Dan juga munculnya masalah lingkungan yang mendadak juga turut berperan untuk timbulnya kekerasan verbal. Telivisi sebagai suatu media yang paling efektif dalam menyampaikan berbagai pesan- 
pesan pada masyarakat luas yang merupakan berpotensial paling tinggi untuk mempengaruhi perilaku kekerasan orang tua pada anak.

Verbal abuse dapat terjadi setiap harinya di rumah, rumah yang seharusnya tempat teraman dan tempat berlindung bagi anak tidak lagi menjadi nyaman. Adanya pengertian yang salah dalam memandang anak, dimana anak masih saja dipandang sebagai objek yang wajib menurut kepada orang tua. Padahal belum tentu orang tua selamanya benar. Kebanyakan orang tua terlalu berharap pada anak dan cenderung memaksa agar anak mau menuruti sepenuhnya keinginan mereka, jika tidak maka anak akan mendapat hukuman. Hal inilah yang menjadikan alasan bagi orang tua sering melakukan kekerasan pada anak. Disamping itu, bisa juga dikarenakan riwayat orang tua yang dulunya dibesarkan dalam kekerasan sehingga cenderung meniru pola asuh yang telah mereka dapatkan sebelumnya. Stress, kemiskinan, isolasi sosial, lingkungan yang mengalami krisis ekonomi, tidak bekerja, kurangnya pengetahuan orang tua tentang pendidikan anak serta minimnya pengetahuan agama orang tua yang turut berperan menjadi penyebab orang tua melakukan kekerasan pada anaknya (Soetjiningsih, 2002).

Verbal abuse dianggap sebagai sesuatu yang lazim, namun dibalik itu semua sebenarnya verbal abuse memiliki dampak yang sangat negatif bagi anak, diantaranya: anak kurang peka terhadap perasaan orang lain, perkembangan terganggu, agresif, gangguan emosi, kepercayaan diri akan turun, menjadi penyebab bunuh diri dan menciptakan lingkaran setan kekerasan verbal dalam keluarga. Bahkan semakin tinggi kekerasan yang diterima dapat menyebabkan ingatan berkurang (Soetjiningsih, 2002).
Setiap anak berhak mendapatkan perlindungan dari tindakan kekerasan, kebanyakan dari orang tua tidak mengetahui bahwa anak juga mempunyai hak dan kewajiban sesuai yang tercantum dalam Undang-Undang No.23 tahun 2002 tentang Perlindungan Anak Pasal 13 dan 69 mengatakan bahwa ada perlindungan hukum bagi anak terhadap kekerasan. Pasal 78 dan 80 juga mengatakan bahwa ada sanksi hukum bagi para pelaku tindak kekerasan pada anak, termasuk didalamnya kekerasan verbal. Berdasarkan Peraturan Gubernur Daerah Istimewa Yogyakarta Nomor 34 Tahun 2013 tentang Rencana Aksi Daerah Perlindungan Perempuan dan Anak Korban Kekerasan Tahun 20132017, pasal 4, 5 dan 14 yang menyatakan bahwa pemerintah Yogyakarta melindungi anak-anak dari kekerasan yang dilakukan oleh orang tua.

Kekerasan terhadap anak Indonesia tampaknya masih menghantui di tahun 2013 ini. Komisi Nasional Perlindungan Anak (Komnas PAI) mencatat dalam semester I di tahun 2013 atau mulai Januari sampai akhir Juni 2013 ada 1032 kasus kekerasan anak yang terjadi di Indonesia. Dari jumlah itu kekerasan fisik tercatat ada 294 kasus atau $28 \%$, kekerasan psikis 203 kasus atau $20 \%$ dan kekerasan seksual 535 kasus atau $52 \%$. Data 1032 kasus kekerasan anak di tahun 2013 ini sebenarnya masih lebih baik dibanding tahun 2012 lalu yaitu 2.637 kasus kekerasan. Dari 2637 anak itu, sebanyak 1657 adalah anak perempuan dan 980 adalah anak laki-laki. Jumlah ini meningkat dibanding tahun sebelumnya yakni tahun 2011 dimana tercatat ada 2509 kasus kekerasan anak (Sujatmiko,2013)

Berdasarkan data dari Forum Perlindungan Korban Kekerasan (FPKK) Daerah Istimewa Yogyakarta (DIY) di tahun 2011, korban kekerasan terhadap anak paling tinggi berada di Kota Yogyakarta dengan 
127 kasus. Peringkat kedua berada di Kabupaten Sleman (123 kasus), disusul Kabupaten Bantul (60 kasus), lalu Kabupaten Gunungkidul (48 kasus) dan terakhir Kabupaten Kulonprogo (36 kasus). Jumlah tersebut menurun dibanding 2010 dengan 191 kasus di Kota Yogyakarta, Kabupaten Sleman (184 kasus), Bantul (92 kasus), Gunungkidul (87 kasus) dan terakhir Kulonprogo (60 kasus). Meski terjadi penurunan angka, tidak berarti kasus kekerasan terhadap anak juga telah berkurang (Sujatmiko, 2013).

Penelitian ini akan dilakukan di Dusun Sawahan Kelurahan Pendowoharjo Kecamatan Sewon, Kabupaten Bantul karena berdasarkan wawancara langsung yang dilakukan oleh peneliti menunjukkan bahwa 16 dari 25 anak di daerah ini setiap harinya medapatkan kata-kata yang tidak pantas dari orang tua mereka maupun kalimat yang bersifat mengancam dari orang tua. Orang tua menganggap hal yang biasa jika memarahi anak-anaknya dengan kata-kata yang tidak pantas. Selain alasan tersebut diatas, peneliti juga mempertimbangkan keadaan masyarakat di dusun Sawahan dimana orang tua terutama ibu yang mayoritas memiliki latar belakang pendidikan yang masih rendah yaitu tamat SMP dan $50 \%$ sebagai ibu rumah tangga. Hal itu mengakibatkan stress yang disebabkan himpitan ekonomi yang akan membuat orang tua mudah sekali meluapkan emosi, kekecewaan, kemarahan, dan ketidakmampuannya kepada orang terdekatnya, yaitu anak mereka.

Berdasarkan latar belakang, maka perumusan masalah dalam penelitian ini adalah "bagaimanakah faktor-faktor yang berhubungan dengan perilaku orang tua melakukan kekerasan verbal pada anak usia pra sekolah".
Tujuan umum penelitian ini yaitu untuk mengetahui faktor-faktor yang berhubungan dengan perilaku orang tua melakukan kekerasan verbal pada anak usia pra sekolah, maka tujuan khusus penelitian ini adalah hubungan umur, pendidikan, pendapatan, pengalaman, lingkungan dan sikap orang tua dengan perilaku orang tua melakukan kekerasan verbal pada anak usia pra sekolah. Hipotesis dalam penelitian ini yaitu terdapat hubungan umur, pendidikan, ekonomi, pengalaman, lingkungan dan sikap orang tua dengan perilaku orang tua melakukan kekerasan verbal pada anak usia pra sekolah.

\section{METODE PENELITIAN}

Penelitian ini merupakan jenis penelitian kuantitatif dengan menggunakan metode pendekatan deskriptif analitik. Populasi dalam penelitian ini adalah seluruh orang tua yang memiliki anak usia prasekolah yaitu anak usia 3 sampai 6 tahun di Dusun Sawahan Kelurahan Pendowoharjo Kecamatan Sewon Kabupaten Bantul yaitu sebanyak 93 responden. Cara pengambilan sampel yang telah dilakukan dalam penelitian ini adalah proportionate random sampling, yaitu 76 responden. yaitu teknik pengambilan sampel tiap RT di Dusun Sawahan, Kelurahan Pendowoharjo, Kecamatan Sewon, Kabupaten Bantul. Selanjutnya jumlah responden tiap RT di Dusun Sawahan dipilih secara simple random.

Variabel terikat dalam penelitian ini yaitu perilaku orang tua terhadap kekerasan verbal pada anak pra sekolah, sedangkan variabel bebasnya adalah umur, pendidikan, pendapatan, pengetahuan, sikap, lingkungan dan pengalaman. Penelitian ini menggunakan kuesioner sebagai alat pengumpulan data. Instrumen penelitian dikatakan berkualitas dan dapat 
dipertanggungjawabkan penggunaannya apabila sudah terbukti validitas dan reliabilitas. Uji validitas dilakukan analisis dengan pearson product moment (Notoadmodjo, 2003). Pertanyaan dalam kuesioner ini valid karena nilai $r$ hitung lebih besar daripada $r$ tabel yaitu $(0,632)$. Uji reliabilitas pada penelitian ini menggunakan teknik alfa cronbach, dengan hasil analisis yaitu seluruh instrumen sama dengan atau lebih dari 0,6.

Kuesioner digunakan untuk mengukur pengetahuan, sikap, lingkungan, pengalaman dan perilaku orang tua tentang kekerasan verbal terhadap anak usia prasekolah. Pertanyaan dalam kuesioner untuk mengukur pengetahuan terdiri dari 7 item pertanyaan berkaitan pengertian, bentuk, macam-macam dan dampak kekerasan verbal. Dalam mengukur sikap ada 8 item pertanyaan dan perilaku ada 12 item menggunakan dengan skala likert, dengan pilihan Sering (S), Kadang (K), Jarang (J), dan Tidak Pernah (TP). Pertanyaan pada sikap dan perilaku terdiri dari hal-hal berkaitan ucapan, tindakan dan cara mendidik orang tua yang mengarah kekerasan verbal seperti contoh pertanyaan mengukur sikap yaitu "Pada saat anda menyuruh anak anda untuk tidak bermain handpone/tablet/game. Tapi anak anda tidak mau menuruti anda menyikapinya dengan Langsung mengambil handpone/ tablet/game", sedangkan contoh pertanyaan mengukur perilaku yaitu "Pada suatu hari, anak anda menangis karena tidak mau berangkat sekolah. Maka yang akan anda ucapkan adalah Mau jadi anak bodoh gak sekolah, kalau gak mau sekolah, angon wedhus wae".

Kuesioner untuk mengukur pengalaman ada 8 item dan lingkungan ada 10 item pertanyaan dengan skala guttman dengan pilihan ya dan tidak. Pada pertanyaan berkaitan tentang pengalaman yaitu kejadian yang pernah dialami atau didapatkan berupa kekerasan verbal seperti pengalaman dibentak, dihina dan melihat perilaku kekerasan verbal contoh pertanyaannya "Saya pernah melihat orang tua bertengkar dengan kata-kata kasar? Pada saat saya masih kecil ditakut-takuti oleh orang tua saya kalau saya tidak mau mandi?". Sedangkan pertanyaan tentang lingkungan berkaitan tentang lingkungan sosial dan tempat tinggal sebagai contoh "Orang dilingkungan tempat tinggal anda mempunyai kebiasaan berbicara dengan nada bicara keras? Tetangga anda sering memanggil anaknya dengan sebutan yang tidak baik, misal "cungkring"?"

Metode pengolahan data dengan langkah editing, coding, tabulasi data dan entry data. Pengolahan data tersebut menggunakan bantuan komputer dengan program SPSS for Windows Release 16,0. Analisa data tersebut meliputi analisis univariat dan analisis bivariat yaitu uji chi square $\left(x^{2}\right)$. Nilai Chi Square hitung lebih kecil dari tabel, maka hipotesa nol diterima, dan apabila lebih besar atau sama dengan harga tabel maka hipotesa nol ditolak dan hipotesa alternatif gagal untuk ditolak (Sugiyono, 2002).

\section{HASIL DAN PEMBAHASAN}

Penelitian dilakukan di Dusun Pendowoharjo yang merupakan wilayah administrasi di bawah Kecamatan Sewon Kabupaten Bantul. Secara geografis Dusun Pendowoharjo memiliki karakteristik berada di dataran rendah. Kecamatan Sewon beriklim seperti layaknya daerah dataran rendah di daerah tropis dengan dengan cuaca panas sebagai ciri khasnya.

Secara kependudukan bahwa masyarakat Dusun Pendowoharjo masuk di wilayah Kecamatan sewon yang memiliki jumlah keseluruhan 75.327 orang dengan jumlah penduduk laki-laki 37.795 orang dan penduduk perempuan 37.532 orang. 
Tingkat kepadatan penduduk di Kecamatan Sewon adalah $2766 \mathrm{jiwa} / \mathrm{km}^{2}$. Sebagian besar penduduk Kecamatan Sewon adalah buruh.

Tabel 1.

Hubungan faktor-faktor yang berhubungan dengan Perilaku Orang Tua Melakukan Kekerasan Verbal Pada Anak Usia Pra-Sekolah

\begin{tabular}{ccc}
\hline \multirow{2}{*}{ Variabel } & \multicolumn{2}{c}{ Perilaku Orang Tua } \\
\cline { 2 - 3 } & $x^{2}$ & $P$ \\
\hline Umur & 8,330 & 0,016 \\
Pendidikan & 2,532 & 0,767 \\
Pendapatan & 2,792 & 0,248 \\
Pengetahuan & 44,239 & 0.000 \\
\hline Sikap & 18,698 & 0.000 \\
\hline Pengalaman & 20,476 & 0.000 \\
\hline Lingkungan & 16,631 & 0.000 \\
\hline
\end{tabular}

Hasil penelitian yang ditunjukkan pada tabel 1 menunjukkan bahwa ada hubungan antara umur responden dengan perilaku orang tua melakukan kekerasan verbal pada anak usia pra-sekolah di Dusun Pendowoharjo Kecamatan Sewon Kabupaten Bantul. Analisis data dengan menggunakan uji chi square di dapatkan $\mathrm{x}^{2}=8,330(p=0,016)$.

Umur adalah lama hidup individu terhitung saat mulai dilahirkan sampai berulang tahun (Notoatmojo, 2003). Hasil penelitian ini berbeda dengan teori (Notoatmojo, 2003) dimana semakin cukup umur, tingkat kematangan seseorang akan lebih matang dalam berfikir dan bekerja. Dari hasil penelitian mengindikasikan bahwa dengan bertambahnya umur seseorang belum tentu kematangan dalam berpikir semakin baik, dimana umur seseorang akan termotivasi untuk tidak melakukan kekerasan verbal pada anak pra-sekolah.

Umur mempengaruhi terhadap daya tangkap dan pola pikir seseorang, semakin bertambah usia akan semakin berkembang pula daya tangkap dan pola pikirnya, sehingga pengetahuan yang diperolehnya semakin membaik. Pada usia madya, individu akan lebih berperan aktif dalam masyarakat dan kehidupan social serta lebih banyak melakukan persiapan demi suksesnya upaya menyesuaikan diri menuju usia tua, selain itu orang usia madya akan lebih banyak menggunakan waktu untuk membaca. Kemampuan intelektual, pemecahan masalah dan kemampuan verbal hampir tidak ada pada penurunan usia ini.

Dari hasil penelitian diasumsikan bahwa semakin bertambah umurnya belum tentu semakin bijaksana, hal ini yang ditemukan oleh peneliti di dusun Sawahan Kelurahan Pendowoharjo, Kecamatan Sewon, Bantul dimana umur responden semakin bertambah menunjukkan perilaku yang semakin negatif.

Hasil penelitian menunjukkan bahwa tidak ada hubungan antara pendidikan responden dengan perilaku orang tua melakukan kekerasan verbal pada anak usia prasekolah di Dusun Pendowoharjo Kecamatan Sewon Kabupaten Bantul.

Tingkat pendidikan merupakan jenjang pendidikan terakhir yang ditempuh seseorang tingkat pendidikan merupakan suatu wahana untuk mendasari seseorang berprilaku secara ilmiah. Tingkat pendidikan yang rendah akan susah mencerna pesan atau informasi yang disampaikan (Notoatmodjo, 2003).

Pendidikan diperoleh melalui proses belajar yang khusus diselenggarakan dalam waktu tertentu, tempat tertentu dan kurikulum tertentu, namun dapat diperoleh dari bimbingan yang diselenggarakan sewaktu-waktu dengan maksud mempertinggi kemampuan atau ketrampilan khusus. Dalam garis besar ada tiga tingkatan pendidikan yaitu pendidikan rendah, pendidikan menengah, dan tinggi. 
Masing-masing tingkat pendidikan tersebut memberikan tingkat pengetahuan tertentu yang sesuai dengan tingkat pendidikan.

Pendidikan tentang perilaku orangtua dalam melakukan kekerasan verbal terhadap anak pra sekolah yang positif merupakan suatu proses mengubah kepribadian, sikap, dan pengertian tentang perilaku yang selama ini negatif sehingga tercipta pola perilaku yang baik tanpa ada paksaan dari pihak manapun. Berpedoman pada tujuan pendidikan diperkirakan bahwa semakin meningkatnya pendidikan yang dicapai sebagian besar penduduk, semakin membantu kemudahan pembinaan akan pentingnya perilaku yang positif dalam menghadapi kekerasan verbal pada anak pra sekolah. Dengan demikian pendidikan pada dasarnya merupakan usaha dan tindakan yang bertujuan untuk mengubah pengetahuan, sikap dan keterampilan manusia. Tingkat pendidikan yang cukup merupakan dasar dalam pengembangan daya nalar serta sarana untuk menerima pengetahuan. Kemampuan menerima seseorang akan lebih cepat jika orang tersebut memiliki latar belakang pendidikan yang cukup. Pengertian tersebut menggambarkan pendidikan bukan hanya mempersiapkan masa depan agar lebih cerah saja, melainkan untuk membantu setiap individu mengembangkan faktor psikisnya menuju tingkat kedewasaan. Sejak dini pendidikan harus sudah diberlakukan pada setiap individu agar menjadikan manusia berkualitas dan tidak menimbulkan dampak yang negatif pada dirinya sendiri atau orang lain khususnya.

Diasumsikan bahwa semakin tinggi tingkat pendidikan seseorang maka semakin mampu mengetahui, memahami ataupun menganalisis apa yang disampaikan demikian sebaliknya semakin rendah tingkat pendidikan yang dimiliki maka semakin rendah atau tidak tahu pula seseorang mencerna apa yang menjadi isi pesan dari informasi khususnya dalam hal kerasan yang dilakukan orang tua terhadap anak pra sekolah.

Hasil penelitian menunjukkan bahwa tidak ada hubungan antara pendapatan responden dengan perilaku orang tua melakukan kekerasan verbal pada anak usia pra-sekolah di Dusun Pendowoharjo Kecamatan Sewon Kabupaten Bantul. Pendapatan keluarga seringkali dikaitkan dengan status kemapanan ekonomi suatu keluarga.

Masalah keuangan seringkali mendorong timbulnya stress pada orangtua. Aspek keuangan dapat berupa tingkat penghasilan keluarga yang rendah dandhadapkan pada tuntutan kebutuhan yang tinggi (Munawati, 2011). Status ekonomi sangat berpengaruh pada perkembangan hubungan orang tua dengan anak. Penelitian yang dilakukan Nugroho Akbar (2009) menyebutkan bahwa income yang diperoleh orangtua berpengaruh terhadap tingkat perilaku pengasuhan orangtua. Orangtua dengan penghasilan rendah memiliki tingkat perilaku yang lebih tinggi dalam melakukan kekerasan kepada anak dibandingkan dengan orangtua yang memiliki penghasilan tinggi.

Tingkat kepuasan orangtua terletak pada seberapa baik orangtua mereka merasa mampu memenuhi kebutuhan anakanaknya. Orangtua yang kekurangan sumber daya untuk merawat anak akan mengalami peningkatan perilaku negatif dalam memenuhi tantangan kehidupan sehari-hari. Ketika mengalami kesulitan ekonomi, orangtua akan menjadi mudah marah, tertekan dan frustasi, serta tekanan psikologis mereka akan menurunkan kemampuan pengasuhan yang akan berpengaruh pada kekerasan (Stuart \& Sundeen, 2006). 
Humanika, Solihin, Lianny (2004) berpendapat bahwa orangtua yang memiliki ketidakmatangan emosi berisiko melakukan kekerasan terhadap anak. Berdasarkan analisis tambahan, kemampuan mengendalikan frrustasi yang menjadi salah satu aspek kematangan emosi berkorelasi positif dengan perilaku kekerasan pada anak yang dilakukan orangtua. Didukung oleh penelitian Khusmas, Asniar. Hastarjo, Wimbarti. (1997) yang menyatakan bahwa orangtua yang melakukan kekerasan fisik dilaporkan mempunyai perasaan negatif yang lebih besar (seperti marah, depresi, bingung dan jengkel) dibandingkan dengan orangtua yang tidak melakukan kekerasan fisik pada anaknya.

Dari hasil penelitian diasumsikan bahwa pendapatan yang rendah seorang orangtua akan mengalami peningkatan perilaku yang negatif dimana orangtua akan mudah marah, tertekan dan frustasi yang akan berujung pada kekerasan verbal pada anak pra sekolah.

Hasil penelitian menunjukkan bahwa ada hubungan antara pengetahuan responden dengan perilaku orang tua melakukan kekerasan verbal pada anak usia prasekolah di Dusun Pendowoharjo Kecamatan Sewon Kabupaten Bantul. Pengetahuan adalah segala sesuatu yang ada dikepala kita. Kita dapat mengetahui sesuatu berdasarkan pengalaman yang kita miliki. Selain pengalaman, kita juga menjadi tahu karena kita diberitahu oleh orang lain. Pengetahuan juga didapatkan dari tradisi (Nugroho, 2009).

Pengetahuan (knowledge) adalah suatu proses dengan menggunakan pancaindra yang dilakukan seseorang terhadap objek tertentu dapat menghasilkan pengetahuan dan keterampilan (Notoatmojo, 2003). Pengetahuan seseorang biasanya diperoleh dari pengalaman yang berasal dari berbagai macam sumber seperti, media poster, kerabat dekat, media massa, media elektronik, buku petunjuk, petugas kesehatan, dan sebagainya. Pengetahuan dapat membentuk keyakinan tertentu, sehingga seseorang berperilaku sesuai dengan keyakinannya tersebut (Nugroho, 2009).

Menurut Notoatmodjo (2003), bahwa pengetahuan atau kognitif merupakan domain yang sangat penting untuk terbentuknya tindakan seseorang (overt behavior), dan Rogers (dalam Notoatmodjo, 2003) menyimpulkan bahwa pengadopsian perilaku didasari oleh pengetahuan, kesadaran yang positif, maka perilaku tersebut akan bersifat langgeng (long lasting) namun sebaliknya jika perilaku itu tidak didasari oleh pengetahuan dan kesadaran, maka perilaku tersebut bersifat sementara atau tidak akan berlangsung lama (Notoatmodjo, 2003).

Kebanyakan orang tua tidak begitu mengetahui atau mengenal informasi mengenai kebutuhan perkembangan anak, misalnya anak belum memungkinkan untuk melakukan sesuatu tetapi karena sempitnya pengetahuan orang tua anak dipaksa melakukan dan ketika memang belum bisa dilakukan orang tua menjadi marah, membentak dan mencaci anak. Orang tua yang mempunyai harapanharapan yang tidak realistik terhadap perilaku anak berperan memperbesar tindakan kekerasan pada anak. Serta kurangnya pengetahuan orang tua tentang pendidikan anak dan minimnya pengetahuan agama orang tua melatarbelakangi kekerasan pada anak.

Pandangan yang keliru tentang posisi anak dalam keluarga. Orang tua menganggap bahwa anak adalah seseorang yang tidak tahu apa-apa. Dengan demikian pola asuh 
apapun berhak dilakukan oleh orang tua (Shocib, 2000).

Dari hasil penelitian diasumsikan bahwa pengetahuan sangat berpengaruh kepada perilaku seseorang, dimana bila seseorang mempunyai pengetahuan yang baik tidak menutup kemungkinan mempunyai perilaku yang positif yaitu orang tua tidak akan melakukan kekerasan verbal pada anaknya, begitu pula sebaliknya apabila seseorang mempunyai pengetahuan yang kurang tidak menutup kemungkinan mempunyai perilaku yang negatif yaitu orang tua akan melakukan kekerasan verbal pada anaknya. Hasil penelitian yang dilakukan pada orangtua di dusun Sawahan Kelurahan Pendowoharjo Kecamatan Sewon Bantul, bahwa orangtua yang mempunyai pengetahuan baik sebagian besar mempunyai perilaku yang positif, sedangkan orangtua yang mempunyai pengetahuan kurang sebagian besar mempunyai perilaku yang negatif.

Berdasarkan hasil penelitian menunjukkan bahwa Ada hubungan antara sikap responden dengan perilaku orang tua melakukan kekerasan verbal pada anak usia pra-sekolah di Dusun Pendowoharjo Kecamatan Sewon Kabupaten Bantul. Menurut Notoatmodjo (2003), sikap merupakan reaksi atau respon yang masih tertutup dari seseorang terhadap suatu stimulus atau objek. Manifestasi sikap itu tidak dapat langsung dilihat, tetapi hanya dapat ditafsirkan terlebih dahulu dari perilaku yang tertutup. Sikap merupakan kesiapan untuk bereaksi terhadap objek dilingkungan tertentu sebagai suatu penghayatan terhadap objek.

Orang tua dan anggota keluarga adalah orang pertama yang memberikan peneguhan terhadap sikap seseorang. Kita biasanya akan cenderung untuk menerima penghargaan, seperti pujian, hadiah, dan pengauan dari anggota keluarga kalau kita setuju dengan sikap yang di ekspresikan mereka. Oleh karena itu, peneguhan yang dilakukan orangtua sejak dini bisa membentuk sikap yang di baca sampai besar nanti, termasuk di antaranya tindak kekerasan verbal yang dilakukan orangtua terhadap anaknya.

Semakin kuat satu sikap dalam pemikiran seseorang maka makin besar pengaruhnya terhadap perilaku. Penelitian yang telah dilakukan menunjukkan bahwa sikap yang dibentuk melalui pengalaman pribadi akan semakin kuat daripada sikap yang dibentuk berdasarkan informasi kedua atau sumber yang tidak langsung. Secara spesifik, sepertinya orang tidak hanya bisa menggunakan sikap sebagai dasar perilaku, kita juga bisa membentuk sikap berdasarkan perilaku kita. Menurut Sarwono karena pembentukan sikap yang paling efektif adalah melalui pengalaman sendiri maka para pakar berusaha mengetahui sampai seberapa jauh perilaku dapat mempengaruhi terbentuknya sikap. Sebagaimana sikap dapat berpengaruh pada perilaku, sebaliknya perilaku pun juga dapat membentuk sikap karena perilaku adalah pengalaman yang paling langsung pada diri seseorang (Nugroho, 2009).

Dari hasil penelitian diasumsikan bahwa hubungan antara sikap orangtua yang positif akan membawa perilaku orangtua untuk tidak melakukan kekerasan verbal terhadap anaknya, begitu pula sebaliknya apabila orangtua mempunyai sikap yang negatif akan mempengaruhi perilakunya dalam melakukan kekerasan verbal pada anaknya.

Berdasarkan hasil penelitian menunjukkan bahwa Ada hubungan antara lingkungan responden dengan perilaku orang tua melakukan kekerasan verbal pada anak usia pra-sekolah. Lingkungan juga mempengaruhi tindakan kekerasan pada 
anak. Lingkungan hidup dapat meningkatkan beban perawatan pada anak. Dan juga munculnya masalah lingkungan yang mendadak juga turut berperan untuk timbulnya kekerasan verbal. Televisi sebagai suatu media yang paling efektif dalam menyampaikan berbagai pesanpesan pada masyarakat luas yang merupakan berpotensial paling tinggi untuk mempengaruhi perilaku kekerasan orang tua pada anak.

Orang tua menjadi memiliki masalah berat dalam hubungannya dengan anak-anak mereka. Orang tua menjadi memiliki konsep-konsep yang kuat dan kaku mengenai apa yang benar dan apa yang salah bagi anak-anak mereka. Semakin yakin orang tua atas kebenaran dan nilainilai keyakinannya, semakin cenderung orang tuamemaksakan kepada anaknya (Stuart dan Sundeen, 2006).

Dari hasil penelitian diasumsikan bahwa lingkungan berpengaruh besar terhadap perilaku orangtua dalam melakukan kekerasan verbal terhadap anak pra sekolah, hal ini sesuai dengan hasil penelitian yang dilakukan di dusun Sawahan Kelurahan Pendowoharjo Kecamatan Sewon Bantul, yang diketahui orang tua yang mempunyai lingkungan baik mempunyai perilaku yang cenderung tidak melakukan kekerasan verbal pada anaknya, tetapi sebaliknya orang tua yang mempunyai lingkungan buruk cenderung melakukan kekerasan verbal terhadap anaknya. Berdasarkan hasil penelitian didapatkan bahwa ada hubungan antara lingkungan responden dengan perilaku orang tua melakukan kekerasan verbal pada anak usia pra-sekolah di Dusun Pendowoharjo Kecamatan Sewon Kabupaten Bantul.

Pengalaman merupakan guru yang terbaik (experient is the best teacher), pepatah tersebut bisa diartikan bahwa pengalaman merupakan sumber pengetahuan, atau pengalaman itu merupakan suatu cara untuk memperoleh suatu kebenaran pengetahuan. Oleh sebab itu pengalaman pribadi dapat pula dijadikan sebagai upaya untuk memperoleh pengetahuan. Hal ini dilakukan dengan cara mengulang kembali pengetahuan yang diperoleh dalam memecahkan persoalan yang dihadapi pada masa lalu (Notoatmodjo, 2003).

Perilaku yang didasari oleh pengetahuan akan lebih baik dibandingkan perilaku yang tidak didasari oleh pengetahuan karena didasari oleh kesadaran, rasa tertarik, dan adanya pertimbangan dan sikap positif. Orang tua yang sewaktu kecilnya mendapat perlakuan salah merupakan situasi pencetus terjadinya kekerasan pada anak. Semua tindakan kepada anak akan direkam dalam alam bawah sdar mereka dan akan dibawa sampai kepada masa dewasa. Anak yang mendapat perilaku kejam dari orangtuanya akan menjadi agresif dan setelah menjadi orang tua akan berlaku ejam pada anaknya. Orangtua yang agresif akan melahirkan anak-anak yang agresif, yang pada gilirannya akan menjadi orang dewasa yang agresif pula. Khusmas, Asniar, Hastarjo, \& Wimbarti (1997).

Dari hasil penelitian diketahui bahwa pengalaman orangtua berpengaruh besar terhadap perilaku orangtua dalam melakukan kekerasan verbal terhadap anak prasekolah. Orang tua yang mempunyai pengalaman baik mempunyai perilaku yang cenderung tidak melakukan kekerasan verbal pada anaknya, tetapi sebaliknya orang tua yang mempunyai pengalaman buruk cenderung melakukan kekerasan verbal terhadap anaknya. 


\section{KESIMPULAN}

Pada akhir penelitian ini, maka dapat disimpulkan sebagai berikut :

1. Terdapat hubungan antara umur dengan perilaku orang tua melakukan kekerasan verbal pada anaknya $\left(x^{2}=\right.$ $8,330, p=0,016$ ).

2. Tidak terdapat hubungan antara pendidikan dengan perilaku orang tua melakukan kekerasan verbal pada anaknya $\left(x^{2}=2,532, p=0,767\right)$.

3. Tidak terdapat hubungan antara pendapatan dengan perilaku orang tua melakukan kekerasan verbal pada anaknya $\left(x^{2}=2,792, p=0,248\right)$.

4. Terdapat hubungan antara pengetahuan dengan perilaku orang tua melakukan kekerasan verbal pada anaknya $\left(x^{2}=44,239, p=0,000\right)$.

5. Terdapat hubungan sikap dengan perilaku orang tua melakukan kekerasan verbal pada anaknya $\left(x^{2}=\right.$ $18,698, p=0,000)$.

6. Terdapat hubungan pengalaman dengan perilaku orang tua melakukan kekerasan verbal pada anaknya. $\left(x^{2}=\right.$ $20,476, p=0,000$ )

7. Terdapat hubungan lingkungan dengan perilaku orang tua melakukan kekerasan verbal pada anaknya $\left(x^{2}=\right.$ $16,631, p=0,000)$

\section{DAFTAR PUSTAKA}

Undang-undang Republik Indonesia Nomor 23 Tahun 2002. Diambil online. Retrieved from http://www.kpai.go.id?hukum/Undan g-undang-UU-RI-no-23-tahun-2002tentang-perlindungan-

anak/ditayangkan oleh admin KPAI10-09-2013

Peraturan Gubernur DIY Nomor 34 Tahun 2013 tentang Rencana Aksi Daerah Perlindungan Perempuan dan Anak Korban Kekerasan Tahun 2013-2017. Diambil online. Diakses dari http://www.yogyakarta.bpk.go.id/wp. content/upload/20114/08/pergub-34th-2013-pdf

Choirunnisa. (18 Maret 2008). Dampak kekerasan verbal pada anak. Diambil dari okezone online. Diakses dari http://m.okezone.com

Humanika, Solihin, Lianny. (2004). Tindakan Kekerasan pada Anak dalam Keluarga...Jurnal Pendidikan Penabur - No.03 / Th.III / Desember 2004

Irwanto.(2000). Tindak kekerasan terhadap anak. Surabaya: PT Lutftansa Mediatama.

Khusmas, Asniar, Hastarjo, T. D, Wimbarti, S. (1997). Peran Fantasi agresif tentang perilaku agresif anakanak. Jurnal Psikologi. No 1, 21-29

Munawati. (2011). Hubungan Verbal Abuse dengan Perkembangan Kognitif pada Anak Usia Prasekolah di RW 04 Kelurahan Rangkapan Jaya Baru Depok .Jakarta: Skripsi. Jakarta. Fakultas Ilmu-ilmu Kesehatan Program Studi Ilmu Keperawatan: Universitas Pembangunan Nasional "Veteran"

Nugroho, A (2009). Faktor-faktor yang mempengaruhi orang tua melakukan verbal abuse pada anak usia prasekolah. Skripsi. (tidak diterbitkan). Semarang. Universitas Muhammadiyah Semarang

Notoatmodjo, S. (2003). Metodologi penelitian kesehatan. Edisi revisi. Jakarta: Rineka Cipta

Notoatmojo, S. (2003). Ilmu kesehatan masyarakat: prinsip-prinsip dasar. Jakarta: Rineka Cipta. 2003 
Soetjiningsih. (2002). Tumbuh kembang anak. Jakarta: EGC

Stuart,. \& Sundeen. (2006). Buku saku keperawatan jiwa, ed 3. Jakarta : EGC

Sugiyono. (2002). Statistika untuk penelitian. Bandung: CV. Alfabeta. 2002

Sujatmiko, T. (26 Maret 2013). Kasus kekerasan anak Kota Yogyakarta tertinggi. Diambil dari kedaulatan rakyat. Online. Rerieved from http://krjogja.com/read/166403/kasus -kekerasan-anak-kota-jogja-tertinggi

Shocib, M. (2000). Pola asuh orang tua. Jakarta: Rineka Cipta

Widyastuti, N. (12 April 2006). Sikap Orang Tua Tentukan Perilaku Anak. Diakses dari http://www.pikiranrakyat.com 